\title{
EVALUATION OF FACTORS WHICH CAUSE FEMALE POVERTY IN THE EU BY PANEL DATA ANALYSIS
}

\section{Asst. Prof. Eylül KABAKÇI GÜNAY (Ph.D.)}

Asst. Prof. Onur POLAT (Ph.D.) *

\begin{abstract}
The purpose of the study is to investigate the impact of women's unemployment rates and education levels on poverty in 27 European Union member countries. Therefore, an econometric model has been applied by using EU-27 countries' 2005-2017 data set. The dependent variable representing female poverty is "female at risk of poverty or social exclusion". The independent variables are the unemployment rate of the active female population and \% of women with primary school graduation. While investigating the effect, the augmented mean group estimator $(A M G)$ is used as the econometric analysis method for the model. This estimator is also known as developed by Eberhardt and Teal's (2010).

The unemployment rate of the active female population has statistically significant effects on \% risk offemale's social exclusion and poverty for EU-27 countries, but the primary education graduation ratio has not a statistically significant relationship. The unemployment rate has same-direction relationship with the risk of social exclusion and poverty. Based on this finding, reducing unemployment is a more effective way to eliminate women's poverty in European countries than increasing primary school graduation. In this context, it can be argued that increasing female's labor participation rate in business and employment in European Union countries can effectively prevent female poverty among women.
\end{abstract}

Keywords: Poverty, Female Poverty, European Union, Panel Data Analysis.

JEL Codes: $13, J 16, J 21$.

\footnotetext{
* İzmir Demokrasi University, Faculty of Economic and Administrative Sciences, Department of Economics. İzmir/ Turkey. E-mail: eylul.kabakci@idu.edu.tr

${ }^{*}$ Bilecik Seyh Edebali University, Faculty of Economic and Administrative Sciences, Department of Public Finance. Bilecik/ Turkey. E-mail: onur.polat@ bilecik.edu.tr
}

Makale Gecmisii/Article History 
Yönetim ve Ekonomi Araștırmalarl Dergisi / Journal of Management and Economics Research

Cilt/Volume: 19 Sayl/Issue: 2 Haziran/June 2021 ss. /pp. 40-61

E. Kabakçı Günay, O. Polat Doi: http://dx.doi.org/10.11611/yead.826661

\section{AB'DE KADIN YOKSULLUĞUNA NEDEN OLAN FAKTÖRLERİN PANEL VERİ ANALİZİ ILLE DEĞERLENDİRILMESI}

\section{ÖZET}

Bu çalışma 27 AB ülkesinde kadınların işsizlik oranları ve eğitim seviyelerinin kadın yoksulluğu üzerindeki etkisini araştırmayı amaçlamaktadır. Bu nedenle 27 AB ülkelesinin 2005-2017 veri seti kullanılarak ekonometrik bir model oluşturulmuştur. Kadın yoksulluğunu temsil eden bağımlı değişken yoksulluk veya sosyal dışlanma riski altındaki kadınlar değiş̧kenidir. Bağımsız değiş̧kenler ise aktif kadın nüfusundaki işsizlik oranı ve ilkokul mezunu kadınların yüzdesidir. Etki araştırılırken, model için ekonometrik analiz yöntemi olarak arttırılmış ortalama grup tahmincisi (AMG) kullanılmıştır. Bu tahmincinin, Eberhardt and Teal's (2010) tarafindan geliştirildiği bilinmektedir.

Sonuç olarak, aktif kadın nüfusunun işsizlik oranı, AB-27 ülkeleri için kadınların sosyal dışlanma ve yoksulluk yüzdesi üzerinde istatistiksel olarak anlamlı etkilere sahiptir, ancak ilkögretim mezuniyet oranı istatistiksel olarak anlamlı bir ilişkiye sahip değildir. İssizizlik oranı, sosyal dışlanma ve yoksulluk riski ile aynı yönlü ilişkiye sahiptir. Bu bulgudan yola çıkarak, Avrupa ülkelerinde kadın yoksulluğunu ortadan kaldırmak için işsizliği azaltmanın ilkokul mezuniyetini artırmaktan daha etkili bir yol olduğu söylenebilir. Bu anlamda Avrupa Birliği ülkelerinde kadınların iş hayatına katılımını ve istihdamını artırmaya yönelik adımlar atılarak kadın yoksulluğunun etkin bir şekilde önlenebileceği iddia edilebilir.

Anahtar Kelimeler: Yoksulluk, Kadın Yoksulluğu, Avrupa Birliği, Panel Veri Analizi.

JEL Kodları: I3, J16, J21.

\section{INTRODUCTION}

Poverty is a problem that affects the entire world. Despite the increasing prosperity and wealth in the 20th century, over 700 million people, or $10 \%$ of the world's population, are struggling with poverty according to United Nations. ${ }^{1}$ Poverty still occupies an important place in the world agenda. For example, Welthungerhilfe; the German Organization which is known for fighting hunger issues; declared that Covid-19 would deepen hunger problems worldwide. According to Welthungerhilfe, around 800 million people struggled with hunger in 2019 and the number is expected to reach one billion in the following years (Sülün,2020).

Although the magnitude of poverty is low in high-income countries, it is a problem that exists in every region of the world. For example, the European Union comprises developed and high-income countries, poverty still exists there. While severe material deprivation is not very common in the European Union countries, $10 \%$ of households struggle to feed their families, pay their electricity bills,

\footnotetext{
1 United Nation, Global Issues, Endind Poverty. https://www.un.org/en/sections/issuesdepth/poverty/\#: :text=736\%20million\%20people\%20lived\%20below\%20the\%20international\%20poverty\%20line \%20of,A sia\%20and\%20sub\%2DSaharan\%20Africa. Access Date: 11.07.2020 
or keep homes warm enough. A significant number of Europeans do not have enough savings to face unexpected financial expenses ( $40 \%$ of women and $36 \%$ of men) or cannot take a vacation away from home at least once a year (37\% of women and 35\% of men) by 2016 (EIGE,2016). As seen from the rates, women are more disadvantaged in terms of poverty.

Another feature of poverty discussed is that it can be encountered between the genders at remarkably different. Because of the different gender roles of women and men in a society that they have unequal opportunities to get their rights and to access resources. Thus, women are represented as the more disadvantaged group for the risk of poverty. How and which factors affect female's poverty is a crucial topic of debate in the economics literature.

The report released by European Institute for Gender Equality (EIGE) reveals the current situation of the severity of poverty and differences between genders in poverty in European Union (EU) countries. According to the report named "Poverty, Gender and Intersecting Inequalities in the EU", the EU faces challenges in reaching its goal of saving at least 20 million people from the risk of poverty or social exclusion by 2020. Almost one in four people in the EU live at risk of poverty or social exclusion. Half of them are women. Compared to men, women also maintain their disadvantageous position in the labor markets in Europe. The average employment rate of women is systematically below the employment rate of men. Women are nearly four times more likely to work part-time than men (32\% versus $8 \%$ ), and the in-activity rate of working-age women (20-64 years) is almost twice that of men in Europe (30 $\%$ against $17 \%$ ) (EIGE,2016).

The theoretical and empirical literature has unified and created a consensus regarding the effects of the education level and unemployment rate on poverty. Few studies measure the impact level of these variables on poor females, especially for countries that are members of the European Union. So, this study aims to test the effect of the variables of the female unemployment rate and female graduation from primary education, which are assumed to affect female poverty, on the female poverty and social exclusion variable for 27 European Union member countries from 2005 to 2017. "At the risk of poverty or social exclusion" (AROPE) is used as an indicator of poverty for EU countries. The target indicator AROPE is an aggregate indicator combining income poverty and deprivation. Other indicators which represent females' situation on labor markets and education level of females are the unemployment rate of active female population and \% of women with primary school graduation, respectively.

Since there is a cross-sectional dependency in the data, a second-generation estimator, "Augmented Mean Group (AMG)" estimator, was used. Eberhardt and Teal (2010) developed The AMG estimator as another option to the Pesaran (2006) CCEMG estimator. This estimator removes the constraints and considers the cross-sectional dependency.

The rest of the study is organized as follows. The second section briefly presents background information about poverty and gender inequality. The third section explains the theoretical and empirical 
literature. The fourth section reviews the data and methodology used. Last, the empirical results and conclusion of the study are presented.

\section{THEORETICAL FRAMEWORK OF POVERTY}

According to the definition of poverty, those who do not meet enough food, clothing, and shelter needs, which are necessary for the physical existence of a person, are considered absolutely poor. This definition refers to absolute poverty, and it is universal. To understand the concept of absolute poverty, it is useful to understand what the World Bank's approach is.

Table 1. Current Poverty Thresholds According to Income Levels

\begin{tabular}{|c|c|}
\hline & Daily Income (PPP) (\$) \\
\hline International Absolute Poverty Line & 1.90 \\
\hline Low-Middle Income Countries & 3.20 \\
\hline Upper Middle Income Countries & 5.50 \\
\hline
\end{tabular}

Source: World Bank, https://datahelpdesk.worldbank.org/knowledgebase/articles/193308-there-are-multiple-internationalpoverty-lines-wh Access Date: 17.06.2020

At Table 1, we can see current poverty thresholds according to income levels. The global absolute poverty line was accepted as $\$ 1$ until 2008, and it was $1 . \$ 25$ between $2008-2015$ by World Bank. The international absolute poverty line was increased from $\$ 1.25$ to $\$ 1.90$ in 2015 . The reason for these changes is differences in cost of living occur around the World. To do so, the global poverty line must be updated periodically to reflect these changes. The new global poverty line uses updated prices of the costs of basic food, clothing, and housing needs around the world to get a more realistic view of poverty. In another word, the actual value of $\$ 1.90$ at today's prices is the same as $\$ 1.25$ in 2005 .

However, there is no absolute consensus that such a standard can be set to diagnose poverty. Instead of the definition of absolute poverty, the idea of determining the poverty line according to the general living standard prevailing in a particular society and defining those who are below this limit as "relatively poor" is more appropriate. According to Townsend, physiological and absolute subsistence standards are important, but it is necessary to see the effects of historical and cultural factors on them. Poverty is a concept that can be defined relatively (Menton, 2007: 5). Relative poverty is determined relative to the standard of living prevailing in society and traditionally accepted by members of the community at a time in that society. Standards change with time and place, the poverty line also constantly changes. Accordingly, understanding and measuring poverty should be determined according to the constantly changing and accepted and unacceptable standards in a society (Kalaycioğlu, 2007: 10). Relative poverty is related to the comparison of the income earned by individuals in a society and to define themselves as poor. In this respect, it would be useful to examine how income is shared around the world to understand the depth of relative poverty.

Furthermore, poverty has many dimensions. Poverty comprises income deprivation and a combination of problems such as unemployment, social exclusion, and the inability to cope with natural 
disasters and diseases. When we consider the dimensions, we come across some of them in the literature. For example, Amartya Sen was one of the first to describe poverty as multidimensional. Considering the fundamental rights and freedoms and living standards of individuals, factors such as not accessing sufficient food, not being able to find remedies for diseases, not meeting the need for adequate clothing and shelter, inability to access to clean water resources, unfavorable health conditions and factors restricting individuals' freedom are directly related to economic poverty (Sen,1976).

\subsection{Female Poverty}

For the first time in 1995, "Women's Poverty" has been defined in the $4^{\text {th }}$ World Conference on Women Action Plan. The concept of feminization of poverty first emerged because of empirical studies conducted on whether women live alone or single. Research has shown that parent families (women and children) are poorer. To explain the feminization of poverty, the reasons for the change in family structure, increase in divorce, increase in the rate of having unmarried children and women taking care of children are used (Şener, 2009: 3). The major reasons for female poverty are the exploitation of female labor and the secondary position of the female labor force in the labor market. This situation, which is described as the unregistered labor force, is important for understanding the poverty of women.

On the other hand, the question of women-headed families tends to be poor or not is crucial to define the disadvantaged situation of women' than men'. Some argue linking the poverty experience of all women living alone to only a demographic variable will cause some theoretical and methodological problems regarding the understanding of poverty. For example, the drawback of this approach is that female-headed households are not homogeneous among themselves. Divorced or widowed women who do not have any social security and women who have sufficient financial resources through their husbands working abroad are also included in this group (Uçar, 2011: 24).

According to researches, female-headed households experience poverty much more than maleheaded households. There are also opinions that state these households' responsibility for the intergenerational transfer of poverty. It has been a discourse accepted by international institutions as the head of women on gender and poverty. However, the relationship between the head of women and poverty is not at the same level everywhere. These households are smaller, and their dependency rates are high. According to the researches, female-headed households with a small amount of male income are relatively better than those who have no such income. In the literature, it is seen that the poverty of women-headed families is integrated with female poverty. Besides, there are reasons to consider the poverty of female-headed families like women are discriminated against in the labor force, credit, and other markets, and they own less property than men. Female-headed households with young children face time constraints and may limit working hours. The number of these households has been increasing in many parts of the world in the last 20 years. This is proof that women are getting poorer compared to 
Yönetim ve Ekonomi Arașttrmaları Dergisi / Journal of Management and Economics Research

Cilt/Volume: 19 Sayl/Issue: 2 Haziran/June 2021 ss. /pp. 40-61

E. Kabakçı Günay, O. Polat Doi: http://dx.doi.org/10.11611/yead.826661

men (Dinçoflaz, 2009: 60). The general opinion that female-headed households are the poorest of the poor in the feminist economy is criticized for the following aspects:

- Lack of independent macro and micro-level evidence to confirm this.

- These households are not homogeneous units, have different social, cultural, demographic, and economic structures and are heterogeneous in terms of not being married, separation, divorce and widowhood (Dinçoflaz, 2009: 62).

It can be said that especially in women-headed families, poverty is experienced more severely; the reason for this is that gender roles. It represents an inequality between gender about poverty. To dig deeper and to search for an answer about debates on gender inequality, the gender equality index for Europe should take into consideration.

\subsection{Gender Equality in European Union}

Studies have shown that women are more disadvantaged than men in the European Union in many aspects. According to the report published by European Institute for Gender Equality (EIGE) for 2018, in segregation in employment, the rate for women is $31 \%$; This rate is only $8 \%$ for males. While women in Europe earn an average monthly income of 2249 Euros; men earn an average of 2809 Euros per month. There are also differences in the duration of working life between women and men. While the average working life of women is 34 years, it is 39 years for men. Again, in the employment rate indicator, while the ratio of women is $42 \%$, it is calculated as $57 \%$ for men. In the indicator of being at risk of poverty, which is one of the most important indicators for our study, again women are at a disadvantage. It is seen that the rate of women at risk of poverty is $17 \%$ while this rate is $16 \%$ for men.

Estimates of women in the labor force and employment are lower than men. In many low-income countries, women often work for free on farms or other family businesses. However, in many highincome economies, women increasingly receive higher education as it provides better job opportunities rather than low-skilled and shorter-term jobs. However, access to well-paid jobs for women is unequal in many professions and countries around the world. Tracking gender inequalities in labor force statistics, employment and unemployment patterns by gender is important for analyzing women's place in the labor market. For the EU, in 2019, LFPR for the male population occurs at $64 \%$, but for the female population $51 \%$.

An important tool to measure gender disparity and compare countries' performance with each other is the gender equality index. The Gender equality index is a tool developed by the European Institute for Gender Equality (EIGE) and used to measure the progress of gender equality in the EU. Countries get scores between 0-100. Scores closer to zero reports worse condition, scores closer to 100 reports better condition. The index has 6 basic areas such as work, money, information, time, power, work, and health. 
Table 2. Gender Equality Index Scores by 2020

\begin{tabular}{|c|c|c|c|c|c|c|c|c|}
\hline & $\begin{array}{c}\text { Geographic } \\
\text { Region }(\text { Sub-) } \\
\text { Domain Scores }\end{array}$ & $\begin{array}{c}\text { Overall } \\
\text { Gender } \\
\text { Equality } \\
\text { Index }\end{array}$ & Work & Money & Knowledge & Power & Health & Time \\
\hline 1 & Sweden & 83.6 & 83 & 86.8 & 73.8 & 83.4 & 94.7 & 90.1 \\
\hline 2 & Denmark & 77.5 & 79.6 & 87.1 & 72.3 & 64.9 & 89.9 & 83.1 \\
\hline 3 & France & 74.6 & 72.4 & 86.4 & 66 & 78.3 & 87.4 & 67.3 \\
\hline 4 & Finland & 73.4 & 74.9 & 87.6 & 61.1 & 66.7 & 89.7 & 77.4 \\
\hline 5 & United Kingdom & 72.2 & 76.9 & 81.6 & 70.4 & 56.5 & 93.3 & 69.9 \\
\hline 6 & Netherlands & 72.1 & 77.4 & 86.7 & 67.1 & 50 & 90 & 83.9 \\
\hline 7 & Ireland & 71.3 & 75.5 & 85.5 & 66.9 & 53.4 & 90.9 & 74.2 \\
\hline 8 & Belgium & 71.1 & 74.1 & 88.3 & 71.3 & 55.2 & 86.3 & 65.3 \\
\hline 9 & Spain & 70.1 & 72.9 & 76.7 & 67.4 & 62 & 90.1 & 64 \\
\hline 10 & Luxembourg & 69.2 & 74.1 & 91.8 & 69.5 & 44.8 & 89.6 & 69.1 \\
\hline 11 & Slovenia & 68.3 & 73.3 & 82.4 & 56 & 57.6 & 87.1 & 72.9 \\
\hline 12 & $\begin{array}{c}\text { European Union - } \\
28 \text { countries (1993- } \\
2020)\end{array}$ & 67.4 & 72 & 80.4 & 63.5 & 51.9 & 88.1 & 65.7 \\
\hline 13 & Germany & 66.9 & 72.1 & 86 & 53.7 & 56.6 & 90.5 & 65 \\
\hline 14 & Austria & 65.3 & 76.6 & 86.4 & 64.1 & 39.9 & 91.7 & 61.2 \\
\hline 15 & Italy & 63 & 63.1 & 78.8 & 61.2 & 47.6 & 88.7 & 59.3 \\
\hline 16 & Malta & 62.5 & 73.3 & 82.5 & 65.8 & 32.2 & 92.1 & 64.2 \\
\hline 17 & Portugal & 59.9 & 72.5 & 72.1 & 55.1 & 46.7 & 84.5 & 47.5 \\
\hline 18 & Estonia & 59.8 & 71.5 & 69.4 & 55.5 & 34.6 & 81.9 & 74.7 \\
\hline 19 & Latvia & 59.7 & 74.2 & 65.5 & 49.7 & 44.1 & 78.3 & 65.8 \\
\hline 20 & Bulgaria & 58.8 & 69 & 61.8 & 53.2 & 59.9 & 77.1 & 42.7 \\
\hline 21 & Cyprus & 56.3 & 70.7 & 80.8 & 56.5 & 28.2 & 88.4 & 51.3 \\
\hline 22 & Czech Republic & 55.7 & 67 & 76.7 & 59 & 26.1 & 86.3 & 57.3 \\
\hline 23 & Croatia & 55.6 & 69.2 & 72.2 & 50.4 & 34.8 & 83.7 & 51 \\
\hline 24 & Lithuania & 55.5 & 73.6 & 64.7 & 55.9 & 32.5 & 79.8 & 50.6 \\
\hline 25 & Poland & 55.2 & 67 & 75.1 & 56.5 & 29.1 & 83.2 & 52.5 \\
\hline 26 & Romania & 54.5 & 67.7 & 62 & 51.5 & 38.8 & 71.1 & 50.3 \\
\hline 27 & Slovakia & 54.1 & 66.5 & 74.2 & 60.4 & 26.8 & 85.8 & 46.3 \\
\hline 28 & Hungary & 51.9 & 67.4 & 71.6 & 56.9 & 20.6 & 86.6 & 54.3 \\
\hline 29 & Greece & 51.2 & 64.2 & 71.4 & 55.7 & 24.3 & 83.5 & 44.7 \\
\hline
\end{tabular}

Source: European Institute for Gender Equality, https://eige.europa.eu/gender-equality-index/2020/comparecountries Access Date: 14.01.2021

When we examine Table 2, based on the overall index, Sweden has the highest index score, then Denmark follows, and third place belongs to France. To assess, we have to investigate domains such as work, money, knowledge, power, health and time. Except for the money domain which has Luxembourg; Sweden has first place for the rest of the domains. 
Yönetim ve Ekonomi Arașttrmaları Dergisi / Journal of Management and Economics Research

Cilt/Volume: 19 Sayl/Issue: 2 Haziran/June 2021 ss. /pp. 40-61

E. Kabakçı Günay, O. Polat Doi: http://dx.doi.org/10.11611/yead.826661

When Table 2 is evaluated, it is seen that women are more disadvantaged than men in all European countries. The necessity of empowering women, who are far behind men in terms of time, power and knowledge, is obvious. The disadvantage of women continues in European countries as well.

\section{LITERATURE REVIEW}

There are many studies considering the factors that determine poverty. However, studies on poverty differentiated by gender are relatively less than the general poverty issues. At the literature in this scope, some studies are as follows;

Daly (1992) in their study aims to locate women's poverty. To do so, Daly used some demographic data like male and female-headed households, poverty percentage, etc. belongs to the United States for 1980. Besides, some empirical findings on women's poverty are reviewed. As a result of this research, it shows that women's poverty is largely ignored and, in fact, the position of women in poverty studies is not fully explained.

Oxaal (1997) particularly points out the relationship between education and poverty. In the study, it was stated that the higher level of education makes it easier to alleviate poverty for women. Although countries with high gross national product (GNP) indeed have greater educational equality for males and females, there is a significant difference among poor countries. So the study shows in poor countries level of education can not enough to eliminate poverty.

Ruspini (1998) tried to identify the dynamics of female poverty for Germany and Britain. Ruspini used longitudinal data from the German Socio-Economic Panel (GSOEP) and the British Household Panel Survey (BHPS) to calculate the duration of poverty varies on different marital statuses and parent ship. In this study, she saw that for German women, marital disruption was the most important factor in women's poverty spells; but for British women, this is linked to unemployment and women's burden of care and domestic work. Ruspini pointed out the importance of women's integration/reintegration into the labor market to get rid of vulnerability and to slip into poverty.

Polin and Michele (2012) in their study focused on income poverty mobility only, identifying and analyzing which are the major determinants associated with households' fall into or exit from poverty. They took into consideration 15 EU member states by comparing European Community Household Panel (EHCP) survey data. They also used the panel logit model. Analyses are carried out, grouping EU countries in the five usual geographical clusters. The results show events related to the labor market are the most important in all clusters both because of their frequency and their relevant impact on poverty transitions. Demographic events are, on the contrary, everywhere, much less relevant.

Barcena-Martin and Moro-Egido (2013) tried to understand what has the biggest impact on differences in the gender poverty gap. The study involves single-adult families, building on evidence from the EU-SILC dataset for 2007-8. The static analysis is based on the year 2008 and includes over 
Yönetim ve Ekonomi Araștirmalarl Dergisi / Journal of Management and Economics Research

Cilt/Volume: 19 Sayı/Issue: 2 Haziran/June 2021 ss. /pp. 40-61

E. Kabakçı Günay, O. Polat Doi: http://dx.doi.org/10.11611/yead.826661

39,945 observations of single-adult households from 17 different European countries. The result revealed that systemic effects, such as welfare state policies, the nature of the labor market, the degree of discrimination, and the level of empowerment of women in the world, tend to be more important than individual effects in understanding discrepancies between countries in the gender poverty gap.

Castillo et al.(2014), examine the effect of poverty, social exclusion, and child labor on out-ofschool rates for female children. This empirical study is based on a dynamic panel model for a sample of 216 countries over the period 1970 to 2010. Results based on the generalized method of moments (GMM) of Arellano and Bond (1991). Authors cannot find empirical proof between primary-school-age children's out-of-school rates (female) and the variables used to analyze the effect of poverty and social exclusion.

Kiaušiene (2015) analyzes the relationship between unemployment and poverty for women and men in 28 European Union countries by gender-based unemployment and poverty rate comparison among countries. As a result, an estimation of the correlation between women's unemployment rates and women at risk of poverty showed that deep direct linkages do not exist in all 28 European Union countries. It is also known that, at present, the unemployment rate of women in $28 \mathrm{EU}$ countries is lower than that of men; however, their risk of poverty is higher than that of men.

Caglayan Akay and Sedefoglu (2017) investigate the factors that cause poverty for female and male-headed households in Turkey. They use Household Budget Survey 2013, which was set up by the Turkish Statistical Institution (TSI) to apply Bayesian probit regression. According to the study, the education level of a bachelor for 4 years, master and Ph.D. is the most efficient variable which causes a decline in the likelihood of living under the poverty line for female-headed households.

Aisa et al. (2019) analyze the determinants of poverty by gender among workers in Europe for 25 European countries. These countries are Latvia, Malta, the Netherlands, Norway, Poland, Portugal, Slovenia, Slovak Republic, Spain and the United Kingdom, Austria, Belgium, Bulgaria, Cyprus, Czech Republic, Denmark, Estonia, Finland, France, Hungary, Ireland, Iceland, Italy, Lithuania, Luxembourg. The source of the data is the EU-SILC database of longitudinal data for the period 2010-2013. They also used panel logistic regression to point out the relation. Their studies show that gender equality is superficial. The expected one is women are in a better position as their education level rises, but this is not the case. The reason for this is that women work more in atypical employment, like part-time jobs, because of their domestic duties. Asymmetry between gender also exists among various professions.

İzgi and Dineri (2019) study the effect of primary and upper education on poverty. The period is 2003-2017 while the analyzed countries are Spain, France, Italy, Cyprus, Latvia, Lithuania, Luxemburg, Hungary, Malta, Netherland, Austria, Poland, Portugal, Romania, Slovenia, Slovakia, Finland, Sweden, United Kingdom, Belgium, Bulgaria, Czech Republic, Denmark, Germany, Estonia, Ireland, Greece, Iceland, Norway and Turkey. In modeling the effect of education on poverty, an analysis was made by 
comparing the results of Arellano-Bond, Arellano-Bover and PCSEs (panel corrected linear regression estimates (PCSEs)). As a result, schooling in primary and secondary education has a reverse relationship with the poverty rate. These results reveal the importance of education in preventing poverty.

Jianu (2019) estimates the effect of young people who are not in employment, education, or training on the people (NEET) at risk of poverty rate in the European Union. The study was conducted as not gender-based but for all young people. The period covers 2010-2016 for all EU-28 countries. The econometric method is the panel estimated generalized least square method. Jianu found a positive and statistically significant relationship between NEET rate and poverty for countries in the European Union.

Bingöl and Ayhan (2020) examine the effect of education, unemployment, and not-in-education employment or training (NEET) population on human development in the EU-28 countries during the 2004-2018 period. They applied the panel data analysis by using Common Correlated Effects Mean Group (CCEMG) estimator, the variables unemployment and education are statistically significant in explaining Human Development Index (HDI) across the panel. The model seems statistically significant in the relationship of multidimensional poverty, which is represented by HDI, with education and unemployment. According to the study, a $1 \%$ increase in the unemployment variable decreases HDI by $0.01 \%$, and a $1 \%$ increase in the education variable increases HDI by $0.30 \%$.

As can be seen, different studies have different results on women's poverty. In this context, the period and countries conducted in poverty studies gain importance. The factors affecting female poverty differed in each study according to the region where the study was conducted. In this context, it is important to understand the factors that determine female poverty in European Union countries. Investigating how education and unemployment affect female poverty in European Union countries will also be a guide for the measures to be taken.

\section{METHODOLOGY}

This study aims to determine the variables which have effects on female poverty in $27 \mathrm{EU}$ countries $^{2}$. For this purpose, panel data econometric analysis was established by using EU countries' 2005-2017 data set. Panel data is defined as the gathering of cross-sectional observations belonging to units such as individuals, countries, firms, and households in a certain period. Panel data consists of $\mathrm{N}$ units and $\mathrm{T}$ number of observations corresponding to each unit.

We can summarize the model as: SOCEXC $=\alpha_{1}+\beta_{1}(\mathrm{UNEMP})+\beta_{2}(\mathrm{EDUPRI})+\varepsilon_{i t}$

In our study, the dependent variable is social exclusion and poverty rate; independent variables are; female primary school graduation rate and the unemployment rate of the active female population.

\footnotetext{
${ }^{2}$ Bulgaria, Czech Republic, Estonia, Greece, Crotia, Cyprus, Lithuania, Latvia, Hungary, Poland, Portugal, Romania, Slovakia, Belgium, Denmark, Germany, Ireland, Spain, France, Italy, Luxembourg, Malta, Netherlands, Austria, Slovenia, Finland, and Sweden. 
The reason for choosing these variables is that they are frequently included as variables in the models used in the former studies and as a component in the gender equality index. Since, as is well known, the factors used in calculating the gender equality index affect poverty.

The concept of being at risk of poverty or social exclusion (AROPE) is connected to at least one of three conditions: being at risk of poverty, being severely materially deprived, or living in households with very low work intensity (EIGE,2016). Social exclusion has multi-dimensions. Lack of resources, rights, goods, and services available to society in economic, social, cultural, or political spheres; It includes the inability to take part in normal relationships and activities. It affects both the quality of life of individuals and the equality and harmony of society (European Social Statistics,2002:42). So AROPE is a multilayered concept that represents poverty.

The unemployment rate of the active female population is a variable that has a relationship with the magnitude of women's poverty. This variable, which was used in previous studies on women's poverty, is expected to be an effective tool in eliminating women's poverty. So, it is included in the model.

The percentage of women with primary school graduation is a variable that is linked to poverty. Because as we know, there is a positive relationship between education and income. The primary education variable is used as a component in this analysis to see whether primary education graduation, also known as basic education in European Union countries, affects poverty. In Table 3, we can see the explanation of variables and its sources that we used to create the model.

Table 3: Variables in the Econometric Model Subject to Analysis

\begin{tabular}{|c|c|c|}
\hline Name of the Variables & Explanation of the Variables & Source \\
\hline SOCEXC & Female at Risk of Poverty or Social Exclusion (\%) & World Bank Data Bank \\
\hline UNEMP & Unemployment Rate of Active Female Population (\%) & World Bank Data Bank \\
\hline EDUPRI & $\%$ of Women with Primary School Graduation & World Bank Data Bank \\
\hline
\end{tabular}

Created by Author

\section{a. Cross-Section Dependence Test}

The test of cross-sectional dependency (CD) is a requirement in estimating panel data models. Investigating the cross-sectional dependency between the series in the panel data model is a crucial step in achieving accurate results. Cross-section dependency's focus is determining whether all series will be affected equally by a shock to the section units or not. If cross-sectional dependence is detected in the results, it is important to take other methodological measures that will permit cross-sectional dependence to occur. Taking the result of cross-section dependency into account in the unit root and cointegration tests ensures analysis results more consistent. 
To determine whether cross-sectional dependence is among the series; Breusch-Pagan (1980) LM or Pesaran (2004) CD test can be used. Breusch-Pagan (1980) LM test can be used where the time dimension is greater than cross-sectional dimension ( $\mathrm{T}>\mathrm{N}$ ). Pesaran (2004) CD test can be used if both the time dimension is greater than the cross-sectional dimension and the cross-section dimension is larger than the time dimension $(\mathrm{T}>\mathrm{N}, \mathrm{N}>\mathrm{T})$. If the time dimension of the panel is smaller than the section size of the panel $(\mathrm{T}<\mathrm{N})$, bias-corrected scaled LM (Baltagi, Feng and Kao, 2012) test statistics can be used. For our study, time dimension is equal to 13 , and the cross-sectional dimension is equal to 27. To do so, it is appropriate to apply Pesaran CD test. The cross-sectional dependence null hypothesis is as follows:

$\mathrm{H}_{0}=$ No cross-section dependency. (There is no correlation between units)

$\mathrm{H}_{1}=$ There is cross-section dependency. (There is a correlation between units)

The results of the Pesaran CD test for EU-27 countries are given in Table 4. In the table, it was checked whether there was a cross-sectional dependency at the 5\% significance level for each variable.

\section{Table 4: Cross Section Dependency Test Results}

\begin{tabular}{|c|c|c|c|}
\hline Variables /Tests & SOCEXC & UNEMP & EDUPRI \\
\hline Breusch Pagan LM & p: 0.000 & p: 0.000 & p: 0.000 \\
\hline Pesaran CD & p: 0.000 & p: 0.000 & p: 0.000 \\
\hline Bias Corrected Scale & p: 0.000 & p: 0.000 & p: 0.000 \\
\hline Created by Author & & & \\
\hline
\end{tabular}

According to test results, the null hypothesis will be rejected and the alternative hypothesis will be accepted. It was seen that all the variables have cross-section dependency according to Pesaran CD test. However, Breusch Pagan LM test and bias-corrected scale test were also examined to decide, it was concluded that this variable also had a cross-sectional dependency. For this reason, there is a crosssectional dependency and correlation between units. So applying a 2nd generation unit root test that considers cross-section dependence will be appropriate.

\section{b. Slope Coefficient Heterogeneity}

Pesaran and Yamagata (1980), based on Swamy's (1970) study, proposed asymptotically normal distribution standardized distribution statistics for panel data models where unit size $\mathrm{N}$ and time dimension $\mathrm{T}$ are large. According to Pesaran and Yamagata's novel approach if $\mathrm{N}$ greater than $\mathrm{T}$, a seemingly unrelated regression equation cannot be applied, so their suggestion is to use the developed version of Swamy's heterogeneity test. It is important to examine whether data can be aggregated across countries and whether it is possible to take into consideration the country-specific variability of panel estimates. Besides, to do an effective cointegration analysis for the models, the homogeneity of the sequence should be checked. 


\section{Table 5: Slope Coefficient Heterogeneity for Model}

\begin{tabular}{|l|c|c|}
\hline Null Hypothesis & Delta & p-value \\
\hline $\mathbf{H}_{\mathbf{0}}$ : Slope coefficients are homogenous & 6.376 & 0.000 \\
\hline Created by Author & & \\
\hline
\end{tabular}

In Table 5, we can see the rejection of the null hypothesis through p-value is smaller than 0.05. So we have to reject the null-hypothesis. As a result, slope coefficients are heterogeneous.

\section{c. Unit Root Test}

Unit root tests developed for the absence of correlation between units in the literature are called first-generation tests; tests used in the presence of a correlation between units are called secondgeneration unit root tests. Since there is a correlation between units in the study, a second-generation unit root test will be used. In this study, Pesaran (2003) was preferred as the unit root test. Pesaran (2003) introduced a simple and new process to test unit roots in dynamic panels that serially depend on correlated errors and have cross-section dependence. For this, he expanded the standard DF (or ADF) regressions with the first differences of individual series and cross-sectional averages of lag levels. When applying the Pesaran CADF-CIPS statistics, to find the appropriate lag lengths for the variables, Schwarz Info Criteria (SIC) has been taken into consideration.

$$
\begin{aligned}
& \mathrm{H}_{\mathrm{o}} \text { : Unit root (Non-Stationary) } \\
& \mathrm{H}_{1}=\text { No unit root (Stationary) }
\end{aligned}
$$

As we can see in Table 6, all the variables in the model are stationary in the level and they have not unit root. For this reason, we can use the data at the level.

Table 6. Unit Root Test Results for the Variables

\begin{tabular}{|c|c|c|}
\hline Variables & SIC & Pesaran CADF \\
\hline SOCEXC I(0) & 3.522 & -2.781 \\
$\left(1^{\text {st }} \mathrm{Lag}\right)$ & $(0.008)^{* * *}$ \\
\hline UNEMP I(0) & 2.254 & -2.744 \\
& $\left(2^{\text {nd }} \mathrm{Lag}\right)$ & $(0.012)^{* * *}$ \\
\hline & 2.414 & $-3,138$ \\
EDUPRI I(0) & $\left(1^{\text {st }} \mathrm{Lag}\right)$ & $(0.000)^{* * *}$ \\
\hline
\end{tabular}

Created by Authors, *** means significant at level 1\%, ** level 5\%, * level 10\%.

\section{d. Cointegration Test}

It is ensured that the variables used in the model are stationary in the same order. It will be checked whether the error terms of the regression established with these variables are stationary in the level values. If the error terms are stable in level values, there is cointegration between variables. To define the cointegration is exists or not we used the Westerlund cointegration test. As a result of the test, the null hypothesis should be rejected. So, there is cointegration between variables. 
Table 7. Westerlund Cointegration Test Result

\begin{tabular}{|c|c|c|}
\hline Cointegration Test & Statistics & p-value \\
\hline Westerlund Cointegration Test & -2.309 & 0.010 \\
\hline
\end{tabular}

Created by Author

In Table 7, there is Westerlund cointegration test result. Regarding the p-value, we have to reject the null hypothesis. Cointegration refers that there is a long-term relationship between variables.

\section{e. Panel Causality Test}

The method developed by Dumitrescu and Hurlin (2012) was used to test the existence of a causality relationship between the series. The advantages of this method are that it can consider both the cross-sectional dependency and heterogeneity between the countries, it can be used when the time (T) dimension is smaller than the cross-section size $(\mathrm{N})$, and it can also produce effective results in unbalanced panel data sets (Dumitrescu and Hurlin, 2012). Another feature of the Dumitrescu and Hurlin tests is that it can analyze both in the existence and absence of a cointegrated relationship. For this reason, the Dumitrescu-Hurlin panel causality test was used for causality analysis in this data set where there is no cointegrated relationship.

Table 8. Dumitrescu-Hurlin Causality Test Results

\begin{tabular}{|c|c|c|c|}
\hline $\begin{array}{l}\text { Number of } \\
\text { Causalities }\end{array}$ & Dumitrescu-Hurlin Causality Hypothesises & $\begin{array}{l}\text { Statistics } \\
\text { (Z-BAR) }\end{array}$ & p-value \\
\hline 1 & $\begin{array}{l}\text { Ho: UNEMP does not Granger-cause SOCEXC. } \\
\mathrm{H}_{1} \text { : UNEMP does Granger-cause SOCEXC }\end{array}$ & 6.653 & $0.000 * * *$ \\
\hline 2 & $\begin{array}{l}\mathrm{H}_{0}: \text { SOCEXC does not Granger-cause UNEMP. } \\
\mathrm{H}_{1} \text { : SOCEXC does Granger-cause UNEMP }\end{array}$ & 4.752 & $0.000 * * *$ \\
\hline 3 & $\begin{array}{l}\mathrm{H}_{0} \text { : EDUPRI does not Granger-cause SOCEXC. } \\
\mathrm{H}_{1} \text { : EDUPRI does Granger-cause SOCEXC }\end{array}$ & 6.653 & $0.000 * * *$ \\
\hline 4 & $\begin{array}{l}\mathrm{H}_{0} \text { : SOCEXC does not Granger-cause EDUPRI. } \\
\mathrm{H}_{1} \text { : SOCEXC does Granger-cause EDUPRI }\end{array}$ & 1.281 & 0.200 \\
\hline
\end{tabular}

Created by Authors, *** means significant at level 1\%, ** level 5\%, * level 10\%.

As it is known, while causality tests were performed, the data were analyzed as stationary. The independent variables in our econometric model are stationary at the same level as the dependent variable. As mentioned in Table 8 , for causality 1 , we must reject the null hypothesis. So unemployment rate of the active female population (UNEMP) does Granger cause females at risk of poverty or social exclusion (SOCEXC). For causality 2, we must reject the null hypothesis. So females at risk of poverty or social exclusion (SOCEXC) does Granger cause of unemployment rate of active female population (UNEMP). As a result, there is a two-way causality between these two variables.

For causality 3, we must reject the null hypothesis. So \% of women with primary school graduation (EDUPRI) does Granger-cause of female at risk of poverty or social exclusion (SOCEXC). For causality 4, p-value is greater than 0,05 . So, we have to accept the null hypothesis. Female at risk of poverty or social exclusion (SOCEXC) does not Granger-cause of \% of women with primary school graduation (EDUPRI). We can say there is one-way relationship between \% of women with primary 
school graduation (EDUPRI) and females at risk of poverty or social exclusion (SOCEXC). If we want to determine the direction of the relationship, it is from $\%$ of women with primary school graduation (EDUPRI) to females at risk of poverty or social exclusion (SOCEXC).

\section{f. Estimation of Heterogeneous and Inter-Unit Correlated Panel Data Models: Augmented Mean Group Estimator}

As mentioned before, there is inter-unit correlation and heterogeneity in the cross-sections used in the analysis. Here, the data should be tested with an estimator that takes into consideration these. Hence, the estimator to be applied in our study is the augmented mean group estimator (AMG) (Tatoğlu,2020:72).

Eberhardt and Bond (2009) and Eberhardt and Teal (2010) suggesting that heterogeneity, nonstationary variables, and cross-sectional dependency cause serious deviations in standard panel estimators, and various diagnostic tests confirm this claim, so Eberhardt and Bond (2009) propose a two-step method, the AMG estimator. A second-generation estimator, the "Augmented Mean Group (AMG)" estimator, removes the constraints. AMG is an estimator that considers the cross-sectional dependency. In this method, the first difference of the variables in the model is used and estimation is made with classical OLS by adding time dummies to the model. Then, the obtained dummy variable coefficients are added to the first model, and the model is re-estimated (Eberhardt,2012:64).

Table 9. Augmented Mean Group Estimator (AMG) Results for EU-27

\begin{tabular}{|l|c|c|c|c|}
\hline Variables & Coefficients & Std.Error & Z Value & P-Value \\
\hline UNEMP & 0.207 & 0.093 & 2.22 & $0.026^{* *}$ \\
\hline EDUPRI & -0.136 & 0.124 & -1.09 & 0.274 \\
\hline
\end{tabular}

Created by Authors, *** means significant at level 1\%, ** level 5\%, * level $10 \%$.

In Table 9, we can see the estimation results for all EU-27 countries. When we examine the p values, we can notice UNEMP p-value is smaller than 0.05 . So, we can say UNEMP has a statistically significant relationship with SOCEXC at level 5\%. If UNEMP is increasing by 1\%, SOCEXC will increase by $0.207 \%$. So the unemployment rate of the active female population has a positive relationship with $\%$ of females at risk of poverty or social exclusion. However, to analyze in a more detailed way, it would be a correct method to research the countries subject to the analysis. 
Yönetim ve Ekonomi Araștirmalarl Dergisi / Journal of Management and Economics Research

Cilt/Volume: 19 Sayl/Issue: 2 Haziran/June 2021 ss. /pp. 40-61

E. Kabakçı Günay, O. Polat Doi: http://dx.doi.org/10.11611/yead.826661

Table 10. Augmented Mean Group Estimator (AMG) Group Estimator Country Based Results

\begin{tabular}{|c|c|c|c|}
\hline Codes & Countries & UNEMP & EDUPRI \\
\hline 1 & Belgium & $0.040(0.911)$ & $-0.201(0.235)$ \\
\hline 2 & Bulgaria & $0.315(0.640)$ & $-0.350(0.735)$ \\
\hline 3 & Czech Republic & $0.222 *(0.067)$ & $-0.265(0.168)$ \\
\hline 4 & Denmark & $0.195(0.179)$ & $0.115(0.164)$ \\
\hline 5 & Germany & $-0.576(0.948)$ & $0.105(0.961)$ \\
\hline 6 & Estonia & $-0.506 * * *(0.001)$ & $-0.403(0.225)$ \\
\hline 7 & Ireland & $1.022 * * *(0.000)$ & $-0.653 * * *(0.000)$ \\
\hline 8 & Greece & $0.324 * * *(0.000)$ & $-0.551 * * *(0.000)$ \\
\hline 9 & Spain & $0.117 * *(0.013)$ & $-0.330 * * *(0.002)$ \\
\hline 10 & France & $0.327(0.277)$ & $0.269 * *(0.021)$ \\
\hline 11 & Crotia & $0.288(0.087)$ & $1.014(0.002)$ \\
\hline 12 & Italy & $-0.533(0.145)$ & $-1.226 * * *(0.000)$ \\
\hline 13 & Southern Cyprus & $0.244 * *(0.027)$ & $0.414(0.714)$ \\
\hline 14 & Latvia & $0.403 * * *(0.006)$ & $0.293(0.871)$ \\
\hline 15 & Lithuania & $0.390 *(0.061)$ & $-1.391 * *(0.016)$ \\
\hline 16 & Luxembourg & $-0.471(0.688)$ & $-0.029(0.890)$ \\
\hline 17 & Hungary & $1.122 * * *(0.000)$ & $-1.989 * * *(0.000)$ \\
\hline 18 & Malta & $0.103(0.927)$ & $-0.042(0.828)$ \\
\hline 19 & Netherland & $-0.076(0.126)$ & $-0.491 * * *(0.000)$ \\
\hline 20 & Austria & $-1.094(0.116)$ & $0.191(0.298)$ \\
\hline 21 & Poland & $0.429 * * *(0.006)$ & $0.673 *(0.065)$ \\
\hline 22 & Portugal & $-0.064(0.775)$ & $-0.004(0.964)$ \\
\hline 23 & Romania & $-0.478(0.425)$ & $0.421(0.315)$ \\
\hline 24 & Slovenia & $0.664 * * *(0.000)$ & $0.601 *(0.065)$ \\
\hline 25 & Slovakia & $0.570 * * *(0.007)$ & $0.581(0.319)$ \\
\hline 26 & Finland & $-0.486 *(0.096)$ & $0.299 *(0.052)$ \\
\hline 27 & Sweden & $0.663 *(0.089)$ & $-0.053(0.619)$ \\
\hline
\end{tabular}

Table 10 contains the test results of each country included in the analysis. When the table is investigated, it is seen that; some of the independent variables have a statistically significant relationship with the dependent variable SOCEXC at the Czech Republic, Estonia, Ireland, Greece, Spain, France, Italy, Southern Cyprus, Latvia, Lithuania, Hungary, Netherland, Poland, Slovenia, Slovakia, Finland, and Sweden. For the rest of the countries, there is no statistically significant relationship with none of the variables.

UNEMP has a statistically significant relationship with SOCEXC for Czech Republic, Ireland, Greece, Spain, Southern Cyprus, Latvia, Lithuania, Hungary, Poland, Slovenia, Slovakia, Sweden, Finland and Estonia. The sign is positive in all countries except Finland and Estonia. So we can say clearly when UNEMP is increasing 1\%, SOCEXC is increasing except Finland and Estonia. For Finland and Estonia there is an inverse relationship between female at risk of poverty or social exclusion (\%) and unemployment rate of active female population (\%). When unemployment rate of active female population increases $1 \%$, there is an increase in female at risk of poverty or social exclusion as $0.222 \%$, $1.022 \%, 0.324 \%, 0.117 \%, 0.244 \%, 0.403 \%, 0.390 \%, 1.122 \%, 0.429 \%, 0.664 \%, 0,570 \%$ and $0.663 \%$, respectively. For Finland and Estonia if the unemployment rate of active female population increases 
by $1 \%$, we may expect that female at risk of poverty or social exclusion will decrease by $-0.486 \%$ and $0.506 \%$, respectively.

EDUPRI has a statistically significant relationship with SOCEXC for Ireland, Greece, Spain, France, Italy, Lithuania, Hungary, Netherland, Poland, Slovenia and Finland. The sign is positive for, France, Poland, Slovenia and Finland; but the sign is negative for Ireland, Greece, Spain, Italy, Lithuania, Hungary and Netherland. When $\%$ of women with primary school graduation increases $1 \%$, there is an increase in female at risk of poverty or social exclusion as $0.269 \%, 0,673 \%, 0.601 \%, 0.299$ $\%$, respectively. But for other countries who has negative relationship with EDUPRI coefficients may be referred as that; $0.653 \%, 0.551 \%, 0.330 \%, 1.226 \%, 1.391 \%, 1.989 \%, 0.491 \%$, respectively.

\section{CONCLUSION AND SUGGESTIONS}

As mentioned throughout the study, female poverty remains one of the most fundamental problems of our world, whose well-being is increasing and enriching. It is imperative that the tools to be used to solve this problem, which has different dynamics than the general poverty problem, are selected under these dynamics and divergent points. In this context, it is necessary to determine what measures can give effective results in reducing female poverty. Besides, the inequality between men and women in the EU, which even consists of developed countries in general, continues in the dimensions of work, money, knowledge, power, health, and time; thus, it was stated that it is right to approach poverty based on gender, due to the presence of gender differences. In this respect, how to prevent female poverty is still an up-to-date issue. In this study, the effect of the unemployment rate of the active female population (\%) and \% of women with primary school graduation on the female's risk of social exclusion and poverty was investigated in European Union countries for 2005-2017.

When the analysis results are observed for EU-27; "the unemployment rate" is statistically significant with the dependent variable "the risk of social exclusion and poverty" but " $\%$ of women with primary school graduation" is not statistically significant for all 27 European Union countries. The unemployment rate seems to play a significant role in the risk of social exclusion and poverty. The risk of social exclusion and poverty rises as the unemployment rate increases and decreases as it decreases, according to the analysis conducted for all European countries. If the unemployment rate of the active female population increases by $1 \%$, the risk of social exclusion and poverty will rise by $0.207 \%$ as we consider the coefficient.

When the analysis results are observed as country-based; the unemployment rate of the active female population (\%) has a statistically significant relationship with the risk of social exclusion and poverty for Czech Republic, Ireland, Greece, Spain, Southern Cyprus, Latvia, Lithuania, Hungary, Poland, Slovenia, Slovakia, Sweden, Finland, and Estonia. While detecting the direction of the relationship, the coefficient's sign is positive in all countries except Finland and Estonia. When taking a gander at the course of the connection between the two variables for these nations, it is seen that it has 
Yönetim ve Ekonomi Araștirmalarl Dergisi / Journal of Management and Economics Research

Cilt/Volume: 19 Sayı/Issue: 2 Haziran/June 2021 ss. /pp. 40-61

E. Kabakçı Günay, O. Polat Doi: http://dx.doi.org/10.11611/yead.826661

a linear direction except for Finland and Estonia. So, we can say clearly while the unemployment rate of the active female population is increasing the risk of social exclusion and poverty is increasing too except in Finland and Estonia. For countries other than Finland and Estonia. For Finland and Estonia, it can be said that the transfer expenditures and social aid of these countries should be investigated. Such a result shows that the amount of social aid provided in case of unemployment in these countries is high. Besides, this result points out females in Estonia and Finland are suffering from multidimensional poverty, which describes by Amartya Sen, rather than income poverty.

When we consider the relation between $\%$ of women with primary school graduation and female at risk of poverty or social exclusion (\%) for countries, the $\%$ of women graduating from primary education increases while the risk of social exclusion and poverty increases in some countries while it decreases in others. $\%$ of women graduating from primary education has a statistically significant relationship with the risk of social exclusion and poverty for Ireland, Greece, Spain, France, Italy, Lithuania, Hungary, Netherland, Poland, Slovenia and Finland. The sign of coefficients is positive for France, Poland, Slovenia and Finland; It may be thought that the risk of social exclusion and poverty is increased because women who graduate from primary school are likely to find jobs for lower wages. They have also lowed scores on the gender equality index compared to other countries. So, we can say females who live in these countries are suffering from multidimensional poverty. But the sign of coefficients is negative for Ireland, Greece, Spain, Italy, Lithuania, Hungary and Netherland. For these countries, graduation from primary education has an active role in preventing women's poverty.

The result points out eliminating unemployment might be a more effective method than increasing primary school education to reduce female poverty in European countries. This positive relationship between female poverty and the unemployment rate for EU-27 and Czech Republic, Ireland, Greece, Spain, Southern Cyprus, Latvia, Lithuania, Hungary, Poland, Slovenia, Slovakia, Sweden, is also consistent with previous studies like Ruspini (1998), Polin and Michele (2012), Barcena-Martin and Moro-Egido (2013), Kiaušiene (2015), Jianu (2019) and Bingöl and Ayhan (2020). According to these studies and ours, unemployment is one of the major causes of poverty and social exclusion. In this sense, any precautions aimed at decreasing women's unemployment would also support the reduction of women's poverty. Therefore, every woman should be employed under their abilities and skills to alleviate poverty. But we mentioned before Estonia and Finland's transfer expenditures and social aid should be investigated to reveal the positive relationship between unemployment rate and risk of poverty or social exclusion.

In our study, there was no significant correlation between $\%$ of women with primary school graduation and female at the risk of poverty and social exclusion for all EU-27. As it is known, primary school education is the most basic level of education. This result is consistent with the findings of Oxaal (1997), Çağlayan and Sedefoğlu (2017) and Aisa et al. (2019), which were previously mentioned in the literature. Because in all these studies, it has been determined that women's poverty only decreases as 
Yönetim ve Ekonomi Araștirmalarl Dergisi / Journal of Management and Economics Research

Cilt/Volume: 19 Sayl/Issue: 2 Haziran/June 2021 ss./pp. 40-61

E. Kabakçı Günay, O. Polat Doi: http://dx.doi.org/10.11611/yead.826661

women's education level rises. In this context, it is reasonable that primary school graduation, which is the most basic level of education, does not affect female poverty. But for country-based analysis; France, Poland, Slovenia and Finland have a statistically significant relationship and positive sign for primary education and risk of poverty and social exclusion. These results are consistent with Oxaal (1997), Caglayan and Sedefoglu (2017) and Aisa et al (2019) too. On the contrary; Ireland, Greece, Spain, Italy, Lithuania, Hungary and Netherland have a statistically significant relationship and negative sign for primary education and risk of poverty and social exclusion. So this result is compatible with İzgi and Dineri (2019) for that countries. They claim primary school education has a reverse relationship with female poverty.

In this context, it can be said that women's poverty can be effectively prevented by taking measures to increase women's participation in business life, increasing women's domestic labor visibility, and ensuring women's participation in business life as an individual, especially beyond gender roles such as mother and wife. Besides, the study might be developed with other levels of education and the results might be evaluated as a whole.

\section{REFERENCES}

Aisa, R.L., Arramona G., and Pueyo F. (2019) "Poverty in Europe by Gender: The Role Of Education and Labour Status", Economic Analysis and Policy, 63: 24-34.

Alcock, P. (2006) “Understanding Poverty”, 3rd Edition, Palgrave Mc Millan NewYork.

Baltagi, B., Feng, Q., \& Kao, C. (2012) “A Lagrange Multiplier Test For Cross-Sectional Dependence In A Fixed Effects Panel Data Model”. Journal of Econometrics, 170 (1): 164-177.

Barcena-Martin E., \& Moro-Egido A.(2013) "Gender and Poverty Risk in Europe". Feminist Economics, 19(2): 69-99.

Bingol, U. ve Ayhan, F. (2020) "The Impact of NEET and Labor Market Indicators on Human Development: A Panel Data Analysis for EU-28 Countries", Sosyal Siyaset Konferansları Dergisi, 79, 441-468. https://doi.org/10.26650/ jspc.2020.79.0158

Breusch, T., and Pagan, A. (1980) "The Lagrange Multiplier Test and Its Application to Model Specification in Econometrics", Review of Economic Studies, 47: 239-254.

Credit Suisse Research Institute (2019) "Global Wealth Report", Switzerland. https://www.creditsuisse.com/about-us/en/reports-research/global-wealth-report.html

Çağlayan-Akay, E., \& Sedefoğlu, G. (2017). "What Does Bayesian Probit Regression Tell Us About Turkish Female- And Male-Headed Households Poverty?”, Journal of International Studies, 10(1), 46-62. doi:10.14254/2071-8330.2017/10-1/3 
Yönetim ve Ekonomi Arașttrmaları Dergisi / Journal of Management and Economics Research

Cilt/Volume: 19 Sayl/Issue: 2 Haziran/June 2021 ss. /pp. 40-61

E. Kabakçı Günay, O. Polat Doi: http://dx.doi.org/10.11611/yead.826661

Daly, M. (1992) "Europe's Poor Women? Gender in Research on Poverty", European Sociological Review, 8(1): 1-12. http://www.jstor.org/stable/522314

Dinçoflaz, N. J. (2009) “Kentteki Kadının Yoksulluğu ve Sosyal Yardımlaşma ve Dayanışma Genel Müdürlüğü’nün Kadın Yoksulluğuyla Mücadele Politikaları”, Uzmanlık Tezi, Ankara: TC Başbakanlık Kadının Statüsü Genel Müdürlüğü.

Dumitrescu, E. I. ve Hurlin, C. (2012) "Testing for Granger Noncausality in Heterogeneous Panels", Economic Modelling, 29(4):1450-1460.

Eberhardt, M. (2012) “Estimating Panel Time-Series Models with Heterogeneous Slopes”, The Stata Journal, 12(1): 61-71.

Eberhardt, M., and Teal F. (2010) "Productivity Analysis in Global Manufacturing Production". Discussion Paper 515, Department of Economics, University of Oxford.

EIGE, (2016) "Poverty, Gender and Intersecting Inequalities in the EU", European Institute for Gender Equality, Luxembourg: Publications Office of the European Union. https://eige.europa.eu/sites/default/files/documents/ti_pubpdf_mh0416244enn_pdfweb_201612 08181320.pdf

ESRC, (2020) "Poverty and Social Exclusion" https://www.poverty.ac.uk/definitions-poverty/socialexclusion\#: : :text=Social\%20exclusion\%20is\%20a\%20complex, social\%2C\%20cultural\%20or \%20political\%20arenas. ( 20.06.2020).

European Social Statistics, (2002) "Income Poverty and Social Exclusion", Luxembourg: Office for Official Publications of the European Communities.

GWR, Global Wealth Report, (2020). https://www.credit-suisse.com/about-us/en/reportsresearch/global-wealth-report.html

İzgi, B., \& Dineri, E. (2019) “Avrupa Ülkelerinde Yoksulluk ve Eğitim: Dinamik Panel Veri Analizi”, 1-3 Kasım 2018, Türkiye Ekonomi Kurumu Konferans1, Antalya.

Jianu, I. (2019) "The Effect of Young People Not in Employment, Education or Training, On Poverty Rate in European Union", Journal of Eastern Europe Research in Business and Economics, 2019:1-14. DOI: $10.5171 / 2019.955941$

Kalaycıoğlu, S. (2007) "Yoksulluk Nasıl Anlaşılmalı? Temel Tanımlar, Yaklaşımlar”. SYDV Yoksulluk Üzerine Seminerler Dizisi. Ankara.

Kiaušiene', I.(2015) "Comparative Assessment of Women Unemployment and Poverty in European Union”, Intellectual Economics, 9 (2015): 91-101. 
Yönetim ve Ekonomi Araștirmalarl Dergisi / Journal of Management and Economics Research

Cilt/Volume: 19 Sayı/Issue: 2 Haziran/June 2021 ss. /pp. 40-61

E. Kabakçı Günay, O. Polat Doi: http://dx.doi.org/10.11611/yead.826661

Leopoldo, L.C., Daniel S.S., \& Leopold R. S. (2014) “The Effect of Poverty, Gender Exclusion, and Child Labor on Out-of-School Rates for Female Children”, Journal of Research in Childhood Education, 28:2, 162-181, DOI: 10.1080/02568543.2014.884028

Menton, C. (2007) “An Investigation of the Measurement of Poverty in Ireland”, Dublin: Institute of Public Administration.

Narayan D. Patel, R. Schafft, K. Rademacher, A. Koch, and Schulte S.(1999) "Can Anyone Hear Us ? Voices From 47 Countries”, World Bank Poverty Group.

Oxaal, Z. (1997) "Education and Poverty:A Gender Analysis", BRIDGE Institute of Development Studies, Report No: 53, University of Sussex.

Pesaran, M.H. (2003) “A Simple Panel Unit Root Test in The Presence Of Cross-Section Dependence”, Cambridge Working Papers in Economics, 0346.http://www.econ.cam.ac.uk/researchfiles/repec/cam/pdf/cwpe0346.pdf

Pesaran, M. H. (2004). "General Diagnostic Tests for Cross Section Dependence in Panels", Discussion Papers on IZA, Discussion Paper No. 1240. https://doi.org/10.17863/CAM.5113

Pesaran, M.H., \& Yamagata, T. (2008) "Testing Slope Homogeneity in Large Panels". Journal of Econometrics, 142(1), 50-93.

Polin, V.and Raitono M.(2012) "Poverty Dynamics in Clusters of European Union Countries: Related Events and Main Determinants", University of Verona Working Paper Series, Italy. http://dse.univr.it/workingpapers/PolinRaitanoPovertyDynamicsInEUWpDSEMarzo2012-1.pdf

Ruspini, E. (1998) "Women and Poverty Dynamics: The Case Of Germany and Britain", Journal of European Social Policy, 8(4), Sage Publication, London.

Sen, A.K. (1976) "Poverty: An Ordinal Approach to Measurement", Econometrica: Journal of the Econometric Society.

Sülün D. (2020), “The Impact Of Covid-19 on France's Economy with an Overview on The European Economy", Journal of Research in Economics, Politics \& Finance, 2020, 5(Special Issue): 115136, DOI: $10.30784 /$ epfad.810739

Swamy, P. A. V. (1970) "Efficient Inference in a Random Coefficient Regression Model”. Econometrica 38: 311-323.

Şener, Ü. (2009) “Kadın Yoksulluğu”. TEPAV Değerlendirme Notu.

Tatoğlu, F.Y. (2020) “İleri Panel Veri Analizi”, 4. Baskı „İstanbul: Beta Yayıncılık.

Uçar, C. (2011) “Kadın Yoksulluğu İle Mücadelede Sosyal Politika Araçları ve Etkinlikler”. Uzmanlık Tezi. Ankara: TC Başbakanlık Kadının Statüsü Genel Müdürlüğü. 
World Bank (2020) https://datahelpdesk.worldbank.org/knowledgebase/articles/193308-there-aremultiple-international-poverty-lines-wh (17.06.2020).

\begin{tabular}{|c|c|c|}
\hline $\begin{array}{c}\text { KATKI ORANI / } \\
\text { CONTRIBUTION RATE }\end{array}$ & $\begin{array}{c}\text { AÇIKLAMA / } \\
\text { EXPLANATION }\end{array}$ & $\begin{array}{l}\text { KATKIDA BULUNANLAR / } \\
\text { CONTRIBUTORS }\end{array}$ \\
\hline $\begin{array}{c}\text { Fikir veya Kavram / Idea } \\
\text { or Notion }\end{array}$ & $\begin{array}{l}\text { Araştırma hipotezini veya } \\
\text { fikrini oluşturmak / Form the } \\
\text { research hypothesis or idea }\end{array}$ & $\begin{array}{l}\text { Asst. Prof. Eylül KABAKÇI } \\
\text { GÜNAY (Ph.D.) } \\
\text { Asst. Prof. Onur POLAT (Ph.D.) }\end{array}$ \\
\hline Tasarım / Design & $\begin{array}{l}\text { Yöntemi, ölçeği ve deseni } \\
\text { tasarlamak / Designing } \\
\text { method, scale and pattern }\end{array}$ & $\begin{array}{l}\text { Asst. Prof. Eylül KABAKÇI } \\
\text { GÜNAY (Ph.D.) } \\
\text { Asst. Prof. Onur POLAT (Ph.D.) }\end{array}$ \\
\hline $\begin{array}{c}\text { Veri Toplama ve İşleme / } \\
\text { Data Collecting and } \\
\text { Processing }\end{array}$ & $\begin{array}{c}\text { Verileri toplamak, } \\
\text { düzenlenmek ve raporlamak / } \\
\text { Collecting, organizing and } \\
\text { reporting data }\end{array}$ & $\begin{array}{l}\text { Asst. Prof. Eylül KABAKÇI } \\
\text { GÜNAY (Ph.D.) } \\
\text { Asst. Prof. Onur POLAT (Ph.D.) }\end{array}$ \\
\hline $\begin{array}{l}\text { Tartışma ve Yorum / } \\
\text { Discussion and } \\
\text { Interpretation }\end{array}$ & $\begin{array}{l}\text { Bulguların } \\
\text { değerlendirilmesinde ve } \\
\text { sonuçlandırılmasında } \\
\text { sorumluluk almak / Taking } \\
\text { responsibility in evaluating } \\
\text { and finalizing the findings }\end{array}$ & $\begin{array}{l}\text { Asst. Prof. Eylül KABAKÇI } \\
\text { GÜNAY (Ph.D.) } \\
\text { Asst. Prof. Onur POLAT (Ph.D.) }\end{array}$ \\
\hline $\begin{array}{l}\text { Literatür Taraması / } \\
\text { Literature Review }\end{array}$ & $\begin{array}{c}\text { Çalışma için gerekli literatürü } \\
\text { taramak / Review the } \\
\text { literature required for the } \\
\text { study }\end{array}$ & $\begin{array}{l}\text { Asst. Prof. Eylül KABAKÇI } \\
\text { GÜNAY (Ph.D.) } \\
\text { Asst. Prof. Onur POLAT (Ph.D.) }\end{array}$ \\
\hline
\end{tabular}

Hakem Değerlendirmesi: Dış bağımsız.

Çıkar Çatışması: Yazar çıkar çatışması bildirmemiştir.

Finansal Destek: Yazar bu çalışma için finansal destek almadığını beyan etmiştir.

Teşekkür:

Peer-review: Externally peer-reviewed.

Conflict of Interest: The author has no conflict of interest to declare.

Grant Support: The author declared that this study has received no financial support.

Acknowledgement: 